\title{
PENERAPAN PRINSIP UNCITRAL MODEL LAW DALAM PEMBUKTIAN KASUS TRANSAKSI ELEKTRONIK DI INDONESIA
}

\author{
Asep Ahmad Fauji \\ Fakultas Hukum Universitas Padjadjaran \\ Email : aafauji@gmail.com
}

\begin{abstract}
The use of information technology can no longer be done through a conventional legal system, considering that its activities can no longer be limited by a country's territory. Broader problems also occur for civil problems, because currently e-commerce transactions have become part of national and international commerce. Legal violations with information technology instruments are often difficult to solve. This paper will discuss the related principles of the UNCITRAL Model Law in proving cases of electronic transactions in Indonesia and legal requirements for electronic data as a form of proof of cases of electronic transactions in Indonesia. The conclusion that was obtained was that Indonesia had applied the principle of the UNCITRAL Model Law in Proving Cases of Electronic Transactions with an approach that is similarly functional and approaches the neutrality of a technology. The settlement of e-commerce cases in Indonesia must meet the legal requirements of electronic data as a form of proof of cases of electronic transactions containing written elements, conditions for signatures, and authenticity.
\end{abstract}

Keywords : Transactions; Electronics; Model Law Principles

\begin{abstract}
ABSTRAK
Pemanfaatan teknologi informasi tidak lagi dapat dilakukan melalui sistem hukum konvensional, mengingat kegiatannya tidak lagi bisa dibatasi oleh teritorial suatu Negara. Persoalan yang lebih luas juga terjadi untuk masalah-masalah keperdataan, karena saat ini transaksi e-commerce telah menjadi bagian dari perniagaan nasional dan internasional. Pelanggaran hukum dengan instrumen teknologi informasi seringkali sulit dipecahkan. Tulisan ini akan membahas terkait dengan perapan prinsip UNCITRAL Model Law dalam pembuktian kasus transaksi elektronik di Indonesia dan persyaratan hukum terhadap data elektronik sebagai bentuk pembuktian kasus transaksi elektronik di Indonesia. Kesimpulan yang didapatkan yakni Indonesia telah menerapkan prinsip UNCITRAL Model Law dalam Pembuktian Kasus Transaksi Elektronik dengan pendekatan yang secara fugsinya sama dan pendekatan kenetralan suatu teknologi. Penyelesaian kasus e-commerce di Indonesia harus memenuhi persyaratan hukum terhadap data elektronik sebagai bentuk pembuktian kasus transaksi elektronik dengan mengandung unsur tertulis, syarat adanya tanda tangan, dan juga keaslian.
\end{abstract}

\section{Kata Kunci : Transaksi; Elektronik; Prinsip Model Law}

\section{Pendahuluan}

Indonesia saat ini merupakan salah satu negara yang telah terlibat dalam penggunaan dan pemanfaatan teknologi informasi, yang dibuktikan juga dengan banyaknya pengguna internet dalam pengertian positif disamping banyaknya juga penyalahgunaan internet itu sendiri. Kenyataan ini sangat kontras dengan 
ketiadaan regulasi yang mengatur data dimaksud sangat rentan untuk diubah, pemanfaatan teknologi informasi khususnya disadap, dipalsukan dan dikirim ke berbagai dalam lingkup informasi dan transaksi penjuru dunia dalam waktu hitungan detik. elektronik.

Dampak yang diakibatkannya pun bisa

Teknologi informasi dan komunikasi telah mengubah perilaku dan pola hidup masyarakat secara global. Perkembangan teknologi informasi telah pula menyebabkan dunia menjadi tanpa batas (borderless) dan menyebabkan perubahan sosial, budaya, ekonomi dan pola penegakan hukum yang secara signifikan berlangsung demikian cepat. Perkembangan transaksi dalam suau perkembangan dipengaruhi pula oleh perkembangan teknologi.

Pemanfaatan teknologi informasi tidak lagi dapat dilakukan pendekatan melalui sistem hukum konvensional, mengingat kegiatannya tidak lagi bisa dibatasi oleh teritorial suatu Negara. Kemudahan dalam akses dapat dilakukan dari belahan dunia manapun. Sehingga dalam menjalankan sistemnya dibutuhkan kehati-hatian ang tinggi. Semakin banyaknya kasus yang yang melanda masyarakat internet dalam melakukan transaksi elektronik. Penipuan termasuk salah satu kasus yang banyak erjadi. Kerugian yang diterima oleh pengguna internet dalam transaksi, baik sebagai penjual maupun pembeli.

Pembuktian merupakan faktor yang sangat penting, mengingat data elektronik bukan saja belum terakomodasi dalam sistem hukum acara Indonesia. Pada kenyataannya demikian cepat, bahkan sangat dahsyat. Teknologi infomasi telah menjadi instrumen efektif dalam perdagangan global.

Persoalan yang lebih luas juga terjadi untuk masalah-masalah keperdataan, karena saat ini transaksi e-commerce telah menjadi bagian dari perniagaan nasional dan internasional. ${ }^{1}$ Contoh kongkret adalah untuk membayar zakat atau berkurban pada saat Idul Adha. Seseorang yang ingin memberikan zakat, cukup mengirimkan sejumlah dana pada nomor rekening bank tertentu. Lalu terjailah sebuah transaksi zakat. Semakin mudahnya sebuah transaksi dapat dilakukan. Transaksi apapun dapat dilakukan dalam waktu yang sangat singkat.

Kenyataan ini menunjukkan bahwa konvergensi di bidang telematika berkembang terus tanpa dapat dibendung, seiring dengan ditemukannya Hak Cipta dan paten baru di bidang teknologi informasi. ${ }^{2}$ Semakin banyaknya kemajuan pada transaksi

${ }^{1}$ Saat ini PBB melalui Komisi khususnya, UNCITRAL, telah mengeluarkan 2 guidelines yang terkait dengan transaksi elektronik, yaitu UNCITRAL Model Law on Electronic Commerce with Guide to Enactment 1996, United Nations Publication, New York, 1999, dan UNCITRAL Model Law on Electronic Signature with Guide to Enactment 2001, United Nations Publication, New York, 2002

${ }^{2}$ Pembahasan lebih lanjut tentang hal ini dapat dilihat pada Rosenoer, Jonathan, CyberLaw: The Law of The Internet, Springer-Verlag, New York, 1996, hlm. $1-20$. 
perdagangan dengan menggunakan iternet, maka semakin banyak pula regulasi yang dipersiapkan untuk melindungi penggunanya.

Kegiatan siber meskipun bersifat virtual tetapi dikategorikan sebagai tindakan dan perbuatan hukum yang nyata. Secara yuridis untuk ruang siber sudah tidak pada tempatnya lagi untuk mengkategorikan sesuatu dengan ukuran dan kualifikasi konvensional untuk dapat dijadikan obyek dan perbuatan, sebab jika cara ini yang ditempuh akan terlalu banyak kesulitan dan hal-hal yang lolos dari jerat hukum. Kegiatan siber adalah kegiatan virtual tetapi berdampak sangat nyata meskipun alat buktinya bersifat elektronik, dengan demikian subyek pelakunya harus dikualifikasikan pula sebagai telah melakukan perbuatan hukum secara nyata.

Salah satu hal penting adalah masalah keamanan. Terdapat tiga pendekatan untuk mempertahankan keamanan di cyberspace: ${ }^{3}$ (1) pendekatan teknologi;

(2) pendekatan sosial budaya-etika; (3) pendekatan hukum. Mengatasi gangguan keamanan pendekatan teknologi memang mutlak dilakukan. Selain itu, pendekatan hukum dan sosial budayaetika sebagai bentuk pendekatan berikutnya menjadi sangat penting. Pendekatan hukum dalam bentuk tersedianya hukum positif akan memberikan jaminan kepastian dan sebagai landasan penegakan hukum (law

\footnotetext{
${ }^{3}$ Ahmad M. Ramli, Cyberlaw dan Haki Dalam Sistem Hukum Indonesia, Refika Aditama, Bandung, 2004, hlm. 2
}

enforcement) jika terjadi pelanggaran.

Pelanggaran hukum dalam transaksi perdagangan elektronik dan perbuatan hukum di dunia maya lainnya merupakan fenomena yang sangat mengkhawatirkan, mengingat tindakan carding, hacking, cracking, phising, booting, viruses, cybersquating, pornografi, perjudian, penipuan, terorisme, penyebaran informasi destruktif (cara pembuatan dan penggunaan bom) telah menjadi bagian dari aktivitas perbuatan pelaku kejahatan internet dan Information and Communication Techonology (ICT).

Pelanggaran hukum dengan instrumen teknologi informasi seringkali sulit dipecahkan, karena di samping perbuatan melawan hukum itu dilakukan oleh subyek yang menggunakan sarana teknologi canggih dan sulit dilacak keberadaannya. Kegiatan dimakud seringkali dilakukan dari luar teritorial Indonesia atau sebaliknya di mana subyeknya berada di Indonesia tetapi modusnya dan lex loci delicti- nya terjadi di luar Indonesia, hal ini menyebabkan pembuktiannya menjadi lebih sulit dibandingkan dengan perbuatan melawan hukum biasa.

$$
\text { Indonesia sudah selayaknya }
$$
merefleksikan diri dengan negara-negara lain seperti Malaysia, Singapura, India, atau negara- negara maju seperti Amerika Serikat dan negara-negara Uni Eropa. Negara-negara maju tersebut secara serius mengintegrasikan regulasi yang terkait dengan pemanfaatan 
teknologi informasi ke dalam instrumen hukum positif (existing law) nasionalnya. ${ }^{4}$

Indonesia yang juga merupakan anggota PBB menerapkan prinsip-prinsip UNCITRAL Model Law sebagai payung hukum dalam membuat regulasi terkait transaksi e-commerce. Tujuan utama dan khusus dari Model Law ini adalah: "(1) memberikan aturan mengenai e-commerce yang ditujukan kepada badan legislatif nasional atau badan pembuat UU suatu negara: (2) meberikan aturan yang bersifat lebih pasti untuk transaksi perdagangan secara elektronik."

Penerapan prinsip Model Law dalam pembuktian sangat dibutuhkan dalam penanganan suatu kasus hukum transaksi elektronik. Maka dari itu, Indonesia mengambil prinsip tersebut untuk diterapkan sebagai cara pembuktian dalam proses penyelesaian kasus. Hal tersebut akan dibahas secara mendalam melalui tulisan ini yakni terkait perapan prinsip UNCITRAL Model Law dalam pembuktian kasus transaksi elektronik di Indonesia dan persyaratan hukum terhadap data elektronik sebagai bentuk pembuktian kasus transaksi elektronik di Indonesia.

\footnotetext{
${ }^{4}$ Ahmad M. Ramli, Eamonn Leonard, Paul Kimberley, et.al., Harmonisation and Enactment Planning for E-Commerce Related Legislation, Jakarta, June 2004.

${ }^{5}$ Huala Adolf, Hukum Perdagangan Internasional, PT. Raja Grafindo Persada, Jakarta, Cetakan ke-5. 2013, hlm. 168
}

\section{Pembahasan}

\section{Prinsip-Prinsip Hukum Pembentukan}

\section{Regulasi Mengenai Transaksi}

\section{Elektronik}

Ruang siber (cyber space) merupakn ruang yang di dalamnya pelaku pelanggaran seringkali menjadi sulit dijerat karena hukum dan pengadilan Indonesia tidak memiliki yurisdiksi terhadap pelaku dan perbuatan hukum yang terjadi, mengingat pelanggaran hukum bersifat transnasional tetapi akibatnya justru memiliki implikasi hukum di Indonesia. Dalam hukum internasional, dikenal tiga jenis jurisdiksi, yakni jurisdiksi untuk menetapkan undang-undang (the jurisdiction to prescribe), jurisdiksi untuk penegakan hukum (the jurisdiction to enforce), dan jurisdiksi untuk menuntut (the jurisdiction to adjudicate). ${ }^{6}$

Kaitan dengan penentuan hukum yang berlaku dikenal beberapa asas yang biasa digunakan, yaitu: ${ }^{7}$ pertama, subjective territoriality, yang menekankan bahwa keberlakuan hukum ditentukan berdasarkan tempat perbuatan dilakukan dan penyelesaian

${ }^{6}$ Darrel Menthe, "Jurisdiction in Cyberspace: A Theory of International Sraces", available at http://www.mttlr.org/volfour/menthe.html, hlm. 2. Cf. Walker, Clive, Andrew Ashworth, The Criminal Law Review, Special Edition, Sweet \& Maxwell, 1998, hlm. 51 dst. Cf. Koop, Bert- Jaap, (ed.), ICT Law and Internationalisation, A Survey of Government Views, Kluwer Law International, 2000, hlm. 40 dst.

${ }^{7}$ Lih. Ahmad M. Ramli, Perkembangan Cyber Law Global dan Implikasinya Bagi Indonesia, Makalah Seminar The Importance of Information System Security in E-Government, Tim Koordinasi Telematika Indonesia, Jakarta, 28 Juli 2004, hlm. 5-6 
tindak pidananya dilakukan di negara lain. Kedua, objective territoriality, yang mungkin dikembangkan untuk internet menyatakan bahwa hukum yang berlaku piracy, seperti computer, cracking, carding, adalah hukum dimana akibat utama hacking, viruses dan lain-lain. Namun perlu perbuatan itu terjadi dan memberikan dipertimbangkan bahwa penggunaan asas ini dampak yang sangat merugikan bagi negara hanya diberlakukan untuk kejahatan sangat yang bersangkutan. Ketiga, nationality yang serius berdasarkan perkembangan dalam menentukan bahwa negara mempunyai hukum internasional.

jurisdiksi untuk menentukan hukum berdasarkan kewarganegaraan pelaku. dibutuhkan suatu hukum baru yang Keempat, passive nationality yang menggunakan pendekatan yang berbeda menekankan jurisdiksi berdasarkan dengan hukum yang dibuat berdasarkan kewarganegaraan korban. Kelima, protective batas-batas wilayah. Ruang siber dapat principle yang menyatakan berlakunya hukum didasarkan atas keinginan negara untuk melindungi kepentingan negara dari kejahatan yang dilakukan di luar wilayahnya, yang umumnya digunakan apabila korban adalah negara atau pemerintah, dan keenam, asas Universality. ${ }^{8}$

Asas

Universality selayaknya memperoleh perhatian khusus terkait dengan penanganan hukum kasus-kasus siber. Asas ini disebut juga sebagai "universal interest jurisdiction". Pada mulanya asas ini menentukan bahwa setiap negara berhak untuk menangkap dan menghukum para pelaku pembajakan. Asas ini kemudian diperluas sehingga mencakup pula kejahatan terhadap kemanusiaan (crimes against humanity), misalnya penyiksaan, genosida, pembajakan udara, dan lain-lain. Meskipun di diibaratkan sebagai suatu tempat yang hanya dibatasi oleh screens and passwords. ${ }^{9}$ Secara radikal, ruang siber telah mengubah hubungan antara legally significant (online) phenomena and physical location. ${ }^{10}$

Berdasarkan karakteristik khusus yang terdapat dalam ruang siber dimana pengaturan dan penegakan hukumnya tidak dapat menggunakan cara-cara tradisional, beberapa ahli berpandangan bahwa sebaiknya kegiatan-kegiatan dalam cyberspace diatur contoh tentang tumbuhnya the law of merchant (lex mercatoria) pada abad pertengahan ${ }^{11}$ Asas, kebiasaan dan norma yang mengatur ruang siber ini yang tumbuh dalam praktek dan diakui secara umum

${ }^{9}$ David R. Johnson and David Post, "Law and Borders : The Rise of Law in Cyberspace", 481 Stanford Law Review 1996, hlm. 1367

${ }^{10}$ Ibid., hlm.1370

${ }^{11}$ Ibid., hlm. 1389 oleh hukum tersendiri, dengan mengambil 
disebut sebagai Lex Informatica.

Sengketa-sengketa di ruang siber (cyber space) juga terkait dengan Hukum Perdata Internasional, antara lain menyangkut masalah kompetensi forum yang berperan dalam menentukan kewenangan forum (pengadilan dan arbitrase) penyelesaian kasus-kasus perdata internasional (HPI). Terdapat dua prinsip kompetensi dalam HPI: pertama, the principle of basis of presence, yang menyatakan bahwa kewenangan pengadilan untuk mengadili ditentukan oleh tempat tinggal tergugat. Kedua, principle of effectiveness yang menyatakan bahwa kewenangan pengadilan ditentukan oleh di mana harta-benda tergugat berada. Prinsip kedua ini penting untuk diperhatikan berkenaan dengan pelaksanaan putusan pengadilan asing (enforcement of foreign judgement).

Asas kompetensi ini harus dijadikan dasar pilihan forum oleh para pihak dalam transaksi e-commerce. Kekecualian terhadap asas ini dapat dilakukan jika ada jaminan pelaksanaan putusan asing, misalnya melalui konvensi internasional. $^{12}$

Berdasarkan karakteristik khusus yang terdapat dalam ruang siber maka dapat dikemukakan beberapa teori sebagai berikut: Pertama, The Theory of the Uploader and the

\footnotetext{
${ }^{12}$ Sebagai contoh adalah Konvensi tentang Pengakuan dan Pelaksanaan Putusan Arbitrase Asing (The Convention on the Recognition and Enforcement of Foreign Arbitral Award - New York 1958)
}

Download. ${ }^{13}$ Berdasarkan teori ini, suatu negara dapat melarang dalam wilayahnya, kegiatan uploading dan downloading yang diperkirakan dapat bertentangan dengan kepentingannya. Misalnya, suatu negara dapat melarang setiap orang untuk uploading kegiatan perjudian atau kegiatan perusakan lainnya dalam wilayah negara, dan melarang setiap orang dalam wilayahnya untuk downloading kegiatan perjudian tersebut. Minnesota adalah salah satu negara bagian pertama yang menggunakan jurisdiksi ini.

Kedua, teori The Law of the Server. ${ }^{14}$ Pendekatan ini memperlakukan server di mana webpages secara fisik berlokasi, yaitu yang dicatat sebagai data elektronik. Menurut teori ini sebuah webpages yang berlokasi di server pada Stanford University tunduk pada hukum California. Namun teori ini akan sulit digunakan apabila uploader berada dalam jurisdiksi asing. Ketiga, The Theory of International Spaces. ${ }^{15}$ Ruang siber dianggap sebagai the fourth space, yang menjadi analogi adalah tidak terletak pada kesamaan fisik, melainkan pada sifat internasional, yakni sovereignlessquality.

\section{Kasus Transaksi Elektronik yang \\ Terjadi Di Indonesia}

Undang-undang Informasi dan

Transaksi Elektronik adalah ketentuan yang berlaku untuk setiap orang yang melakukan

\footnotetext{
${ }^{13}$ Darrel Menthe, op.cit., hlm. 3 - 4

${ }^{14}$ Ibid, hlm. 5

${ }^{15}$ Ibid, hlm. 7 - 8
} 
perbuatan hukum sebagaimana diatur dalam Undang-Undang ini, baik yang berada di wilayah hukum Indonesia maupun di luar wilayah hukum Indonesia, yang memiliki akibat hukum di wilayah hukum Indonesia dan/atau di luar wilayah hukum Indonesia dan merugikan kepentingan Indonesia.

Secara umum, materi Undang-Undang Informasi dan Transaksi Elektronik (UUITE) dibagi menjadi dua bagian besar, yaitu pengaturan mengenai informasi dan transaksi elektronik dan pengaturan mengenai perbuatan yang dilarang. Pengaturan mengenai informasi dan transaksi elektronik mengacu pada beberapa instrumen internasional, seperti UNCITRAL Model Law on e-Commerce dan UNCITRAL Model Law on e-Signature. Adapun beberapa Contoh Pelanggaran UU ITE, yaitu ${ }^{16}$ :

1. Kasus Penghinaan dan Pencemaran Nama Baik. Florence Sihombing adalah mahasiswa S2 Universitas Gajah Mada Yogyakarta yang harus mendekam di sel Polda DIY usai dilaporkan menghina masyarakat Yogyakarta di sebuah akun Path miliknya. Florence dijerat Pasal 27 ayat 3 UU ITE terkait informasi elektronik yang dianggap menghina dan mencemarkan nama baik. Jerat dalam pasal tersebut mengancam siapa pun

\footnotetext{
${ }^{16}$ http://arufnur.web.ugm.ac.id/2015/03/08/rekmedjarkom-tugas-03-uu-ite-dan-penjelasannya/ (Diakses pada 6 Juni 2016, Pukul 09.00 WIB)
}

yang mendistribusikan dokumen atau informasi elektronik yang bermuatan penghinaan dan atau pencemaran nama baik. Selain itu, kasus ini melanggar Pasal 28 ayat 2 UU ITE karena pelanggarannya memuat pelarangan penyebaran informasi yang menyebarkan kebencian.

2. Kasus Perjudian Online. Perjudian online, pelaku menggunakan sarana internet untuk melakukan perjudian. Seperti yang terjadi di Semarang, Desember 2006 silam. Para pelaku melakukan praktiknya dengan menggunakan system member yang semua anggotanya mendaftar ke admin situs itu, atau menghubungi HP ke 0811XXXXXX dan 024-356XXXX. Mereka melakukan transaki online lewat internet dan HP untuk mempertaruhkan pertarungan bola Liga Inggris, Liga Italia dan Liga Jerman yang ditayangkan di televisi. Untuk setiap petaruh yang berhasil menebak skor dan memasang uang Rp 100 ribu bisa mendapatkan uang Rp 100 ribu, atau bisa lebih. Modus para pelaku bermain judi online adalah untuk mendapatkan uang dengan cara instan. Dan sanksi menjerat para pelaku yakni dikenakan pasal 303 tentang perjudian dan UU 7/1974 pasal 8 yang ancamannya lebih dari 5 tahun. Kasus ini melanggar Pasal 27 ayat 2 UU ITE, yaitu "Setiap Orang dengan sengaja 
dan tanpa hak mendistribusikan dan/atau mentransmisikan dan/atau membuat dapat diaksesnya Informasi Elektronik dan/atau Dokumen Elektronik yang memiliki muatan perjudian".

3. Kasus Data Forgery. Kasus ini terjadi hari Rabu 17 April 2004, Dany Firmansyah 25 tahun, seorang konsultan teknologi informasi (TI) PT. Dana reksa di Jakarta, berhasil membobol situs milik KPU di http://tnp.kpu.go.id dan mengubah nama-nama partai didalamnya menjadi nama unik seperti partai kolor ijo, partai mbah jambon, partai jambu dan lain sebagainya. Dani menggunakan teknik SQL injection (pada dasarnya teknik tersebut adalah dengan cara mengetikkan string atau perintah tertentu di addres bar browser) untuk menjebol situs KPU. Kemudian dani tertangkap pada Kamis, 22/4/2004. Kasus ini melanggar UU ITE No 11 Pasal 30 Ayat 3 Tahun 2008, yang berbunyi : "Setiap Orang dengan sengaja dan tanpa hak atau melawan hukum mengakses Komputer dan/atau Sistem Elektronik dengan cara apa pun dengan melanggar, menerobos, melampaui, atau menjebol sistem pengamanan", karena Dani Firmansyah telah terbukti melakukan penghinaan dan pencemaran nama baik partai-partai yang ada dalam situs KPU dengan cara mengganti-ganti nama partai tersebut dan melakukan menjebolan sistem keamanan pada situs KPU.

4. Kasus Pembobolan Internet Banking Milik BCA. Pada tahun 2001, Internet Banking diributkan oleh kasus pembobolan internet banking milik bank BCA, Kasus tersebut dilakukan oleh seorang mantan mahasiswa ITB Bandung dan juga merupakan salah satu karyawan media online (satunet.com) yang bernama Steven Haryanto. Anehnya Steven ini bukan Insinyur Elektro ataupun Informatika, melainkan Insinyur Kimia. Ide ini timbul ketika Steven juga pernah salah mengetikkan alamat website. Kemudian dia membeli domain-domain internet dengan harga sekitar US\$20 yang menggunakan nama dengan kemungkinan orang-orang salah mengetikkan dan tampilan yang sama persis dengan situs internet banking BCA. Kasus ini melanggar Pasal 35 UU ITE tahun 2008 : "Setiap orang dengan sengaja dan tanpa hak atau melawan hukum melakukan manipulasi, penciptaan, perubahan, penghilangan, pengrusakan informasi elektronik dan/atau dokumen elektronik dengan tujuan agar informasi elektronik dan/atau dokumen elektronik tersebut seolah-olah data yang otentik (Phising $=$ penipuan situs)". 


\section{Pembuktian pada Transaksi}

\section{Elektronik Berdasarkan Uncitral}

Model Law

Pembuktian pada setiap kasus transaksi elektronik yang diterapkan di Indonesia diambil dari prinsip Model Law. Prinsip ini yang kemudian digunakan dalam menyelesaikan kasus transaksi elektronik. Sehingga kasus tersebut dapat diselesaikan dengan suatu persamaan dalam pembuktian. Pembuktian dengan menggunakan data elektronik pada mulanya belum dianggap sah dalam pembuktian. Namun, sekarang data eletronik menjadi nilai bukti yang sama setelah Model Law diterapkan.

Prinsip Model Law terdiri dari functional equivalence approach (pendekatan yang secara fungsinya sama) dan technology neutrality approach (pendekatan kenetralan suatu teknologi). ${ }^{17}$ Pendekatan ini yang kemudian mempersamakan data elektonik dengan data konvensional lainnya. Seperti data-data berbentuk dokumen kertas yang dapat dijadikan alat bukti. Data-data eletronik tersebut diperlakukan sama layaknya sebagai data secara umum.

Pembuktian di dalam peradilan, data eletronik harus dipersamakan dengan data dokumen lainnya. Sehingga pesan data tersebut tetap dapat dipergunakan sebagai alat bukti. Kriteria sebagai pesan data terdiri dari: $^{18}$ “(1) asal dari pesan data, disimpan

\footnotetext{
${ }^{17}$ Huala Adolf, op cit, hlm. 170

${ }^{18}$ Pasal 9 UNCITRAL Model Law
}

atau didokumentasikan; (2) integritas dari informasi; (3) dikenalnya si pembuat aslinya; dan (4) faktor-faktor lainnya yang relevan dengan informasi."

Setiap transaksi internasional didahului adanya suatu perjanjian. Perjanjian dapat dilakukan secara internasional atau multilateral. Perjnjian tersebut kesepakatan tertulis tersebut mengikat bagi para pihak yang melakukan perjanjian. Perjanjian tertulis ini yang kemudian dijadikan alat bukti. Pesan data termasuk yang dapat dijadikan dokumen. Dokumen inilah yang kemudian dijadikan alat bukti yag sah dalam pembuktian.

Hubungan perdagangan merupakan hubungan bersifat komersial. Hubungan ini sebagian besar bersifat kontraktual. Anatara penjual dan pembeli saling menyepakati suatu perjnjian demi tercapainya tujuan dari transaksi tersebut, yaitu keuntungan. Sehingga dalam menjalankan atau memenuhi keinginan tersebut, hendaknya kedua belah pihak mematuhi aturan-aturan yang sesuai dengan aturan yang berlaku. Baik secara nasional maupun internasional.

Penyesuaian Model Law ini dapat dilakukan sesuai dengan kebutuha dari negara yang menerapkan. Hal ini dapat disesuaikan dengan kondisi dan sistem hukum seperti apa yang dianut oleh negara yang menandatanganinya. Indonesia menerapkan prinsip Model Law pada aspek pembuktian dalam kegiatan transaksi bisnis, khususnya transaksi bisnis secara elektronik 
menggunakan Internet.

Oleh sebab itu, maka adanya persamaan yang disesuaikan dengan pembukian dengan negara lain apabila masyarakat Indonesia melakukan suatu transaksi elektronik dengan masyarakat negara lain yang menganut $M$ odel Law pada pembuktiannya pula. Kasus-kasus tersebut dapat diselesaikan pula di negara tertentu sesuai dengan prerjanjian kedua belah pihak. Hal ini berhubungan dengan hukum perdata internasional.

Penerapan persyaratan hukum dilakukan dalam transaksi elektronik. Pada Pasal 5 Model Law yang menitik beratkan akibat hukum terhadap keabsahan suatu data elektronik. Selain itu Pada Pasal 6 hingga Pasal 8 menjelaskan mengenai pesan data elektronik yang dianggap syarat tertulis, serta tanda tangan sebagai syarat originalitas atau keaslian.

Syarat tertulis, tanda tangan dan keaslian merupakan syarat mutlak yang harus dipenuhi dalam keabsahan sebagai alat bukti. Syarat tertulis tersebut mengandung informasi yang dapat diakses. Pesan data kemudian dapat dijadikan rujukan sebagai bahan acuan dalam pemeriksaan selanjutnya dalam menyelesaikan kasus transaksi elektronik.

Syarat tanda tangan merupakan syarat yang harus dipenuhi. Adanya metode tanda tangan yang harus dibubuhi dalam aplikasi format perjanjian. Dalam hal ini tanda tangan dibubuhi dengan mencontreng bagian tertentu. Hal tersebut menandakan bahwa perjanjian tersebut disepakati. Tanda tangan inilah yang menjadikan acuan apakah pihak kedua menyepakati suatu perjanjian transaksi elektronik atau tidak.

Syarat keaslian pada suatu transaksi elektronik yang dimaksud adalah tidak berubahnya data pesan elektronik yang disepakati. Hal-hal yang harus dipenuhi dalam bentuk aslinya yaitu: ${ }^{19}$ (1) Terdapat jaminan mengenai integritas informasi pada waktu pertama kali dituangkan dalam bentuk akhir sebagai suatu pesan data; (2) Informasi dapat ditampilkan kepada suatu pihak yang disyaratkan untuk ditampilkan terhadapnya. Pesan tersebut tidak boleh berubah sesuai dengan yang asli yang di buat pada awal kesepakatan. Keaslian dari pesan data dilihat dari kestabilan muatan yang tidak bisa berubah dalam kondisi apapun.

Syarat keaslian ini sangat sulit untuk diterapkan. Pesan data sudah jelas berbeda dengan dokumen konvensional lainnya, seperti akta tanah. Dokumen tersebut sulit untuk dipalsukan karena berbeda dengan data pesan elektronik. Negara-negara yang menganut penbuktian dokumen konvensional sungguh sulit menerapkan Model Law pasal ini.

Pada Pasal 11 UNCITRAL Model Law dijelaskan bahwa pembautan kontrak melalui e-commerce adalah sah dan mengikat (valid

\footnotetext{
${ }^{19}$ Ibid, hlm 173
} 
and envorceable contract). Kehendak kedua belah pihak, baik pihak pembuat maupun pihak menerima harus memiliki akibat hukum, juga keabsahannya. Hal inilah yang menuntut kedua belah pihak harus berhatihati dalam melakukan perjanjian. Akibat dari ketidak hati-hatian tersebut dapat mengalami kerugian.

\section{Penutup}

Indonesia telah menerapkan prinsip UNCITRAL Model Law dalam Pembuktian Kasus Transaksi Elektronik dengan pendekatan yang secara fugsinya sama dan pendekatan kenetralan suatu teknologi. Penyelesaian kasus e-commerce di Indonesia harus memenuhi persyaratan hukum terhadap data elektronik sebagai bentuk pembuktian kasus transaksi elektronik dengan mengandung unsur tertulis, syarat adanya tanda tangan, dan juga keaslian.

\section{Daftar Pustaka}

\section{Buku- buku}

Ahmad M. Ramli, (2004), Cyberlaw dan Haki Dalam Sistem Hukum Indonesia, Refika Aditama, Bandung.

Ahmad M. Ramli, Eamonn Leonard, Paul Kimberley, et.al., (2004) Harmonisation and Enactment Planning for E-Commerce Related Legislation, Jakarta.

Ahmad M. Ramli, (2004), Perkembangan Cyber Law Global dan Implikasinya Bagi Indonesia, Makalah Seminar The Importance of Information System Security in E-Government,
Tim Koordinasi Telematika Indonesia, Jakarta.

Darrel Menthe, (2000), "Jurisdiction in Cyberspace: A Theory of International Sraces", available at http://www.mttlr.org/volfour/menthe .html, hlm. 2. Cf. Walker, Clive, Andrew Ashworth, The Criminal Law Review, Special Edition, Sweet \& Maxwell, 1998, hlm. 51 dst. Cf. Koop, Bert- Jaap, (ed.), ICT Law and Internationalisation, A Survey of Government Views, Kluwer Law International.

David R. Johnson and David Post, (1996), "Law and Borders: The Rise of Law in Cyberspace", 481 Stanford Law Revie.

E. Brata Mandala, (2004), Ancaman Cyber Terrorism dan Strategi Penanggulangannya di Indonesia, Makalah Seminar The Importance of Information System Security in EGovernment, Tim Koordinasi Telematika Indonesia, Jakarta.

Huala Adolf, (2013), Hukum Perdagangan Internasional, PT. Rajagrafindo Persada, Jakarta.

\section{Peraturan Perundang-undangan}

UNCITRAL Model Law

Undang-undang Nomor 11 Tahun 2008 tentang Informasi dan Transaksi Elektronik

\section{Sumber Lainnya}

UNCITRAL Secretariat, Explanatory Note on the UNCITRAL Model Law on International Credit Transfer, 1991.

www.un.org and www.uncitral.org (Diakses pada 5 Juni 2016, Pukul 22.16 WIB)

http://www.UNCITRAL.,org/English/Worki ngGroup/wg-ec/wp1e.pdf/12/04/2004 
(Diakses pada 6 Juni 2016, Pukul 09.00 WIB)

www.cp.tech.org/ecom/UNCITRAL/12/4/04

(Diakses pada 5 Juni 2016, Pukul 22.21 WIB)

http://arufnur.web.ugm.ac.id/2015/03/08/rek med-jarkom-tugas-03-uu-ite-danpenjelasannya/ (Diakses pada 6 Juni 2016, Pukul 09.00 WIB) 